\title{
Built in Potential of a-Si:H Based p-i-n Solar Cell at Different Energy Gap of Intrinsic Layer
}

\author{
Rahayu Setyo Yuniarsih¹, Endhah Purwandari ${ }^{1, a}$, Misto $^{1}$, Edi Supriyanto ${ }^{1}$ \\ and Supriyadi ${ }^{1}$
}

${ }^{1}$ Department of Physics, Faculty of Mathematics and Natural Sciencs, University of Jember, Jalan Kalimantan No 37 Jember 68121, Indonesia

aendhah.fmipa@unej.ac.id

\begin{abstract}
The photovoltaic process inside a solar cell can be described using the distribution of electrostatic potential in the material. In this paper, the magnitude of the electrostatic potential of the solar cell for the p-i-n junction type is analyzed as the built in potential due to the diffusion activity of electrons and holes. The magnitude of the electrostatic potential is obtained by solving the Poisson and Continuity equations, which are applied to a-Si: $\mathrm{H}$ based materials. The difference in built in potential at the $\mathrm{p}$ - $\mathrm{i}$ and $\mathrm{i}$ $\mathrm{n}$ junctions is obtained as a function of the energy gap of the intrinsic layer.
\end{abstract}

Keywords: Solar Cell, Electrostatic Potential, Built In Potential, Energy Gap

\section{Introduction}

Hydrogenated amorphous silicon (a-Si:H) based solar cells having $\mathrm{p}-\mathrm{i}-\mathrm{n}$ structure have been widely investigated for use as low-cost solar cells [1]. They have also been made using a simple method and an abundance of materials [2]. As an electric power source, a-Si:H p-i-n solar cells requires improvements in collection efficiency and stability. The performance parameters are determined by open-circuit voltage (Voc), short-circuit current (Isc), fill factor (FF) and efficiency $(\eta)$. One of the factors that can increase the short circuit current density is the number of charge carriers generated in the device, due to the photogeneration mechanism. The more increased the number of charge particle generated, the more enhanced the short circuit current produced.

The greatest number of photogeneration process are created in depletion area, where the intrinsic layer plays a major role in the occurrence of the process. Built-in potential generated two conjunctions of intrinsic layer and the two outer layer determines the width of depletion area. The energy gap possessed by the intrinsic layer affects the photogeneration rate produced by the layer. In this paper, various number of energy gap of intrinsic layer have investigated to analyze their effect to the built in potential.

Theoretically, transport mechanism of charge carriers in semiconductor devices is well described using Poisson and continuity equations [3]. Their numerical solution defines the carrier charge of Semiconductor as function of potential electrostatic at operational temperature. Having known the electrostatic potential at the point of the junction in p-i-n solar cell, we can find out the magnitude of the built in potential in it. The study of hydrogenated amorphous siliconbased solar cells in modelling area had investigated since early 1980's. In one-dimensional structure, the conversion mechanism of solar cells has been analyzed by Hack and Shur [4], Tareto et al. [5] Zhu et al. [6], Kabir et al. [7], Usman [8] and Purwandari [3]. 
The measurement of built in potential has been experimentally measured by Olthof using ultraviolet photoemission spectroscopy (UPS) method. He had investigated built in potential in $p$-i-n homojunction of pentacene.The results showed that the potential in $p$-i junction was greater than i-n junction [9]. In this research, the built in potential calculation has been carried out using a numerical approach based on the finite element method. The ease of application of the finite element method is a suitable choice for theoretical studies of solar cells. The finite element method is used to analyze the built-in potential in solar cells with the $p$-i-n connection type for variations in the energy gap and output voltage.

\section{Methods}

A single junction $p-i-n$ amorphous silicon solar cells was presented in one dimensional physically-based computer simulation using Finite Elemen Method Laboratory (Figure 1). The simulator was applied to the analysis of a p-i-n single junction a-SiC:H/a-Si:H/a-Si:H solar cell. The lengths of the $p, i$ and $n$ layer were set at a thickness of $0.015 \mu \mathrm{m}, 0.55 \mu \mathrm{m}$ and $0.03 \mu \mathrm{m}$ respectively. The energy gaps of the $p$ and $n$ layer were $2.36 \mathrm{eV}$ and $1.7 \mathrm{eV}$. In this simulation, the effects of energy gap of intrinsic layer to built in potential were analyzed by varying them from 1.70 to $1.74 \mathrm{eV}$. The extracted features shown in Table 1 are used as the input parameter of simulation.

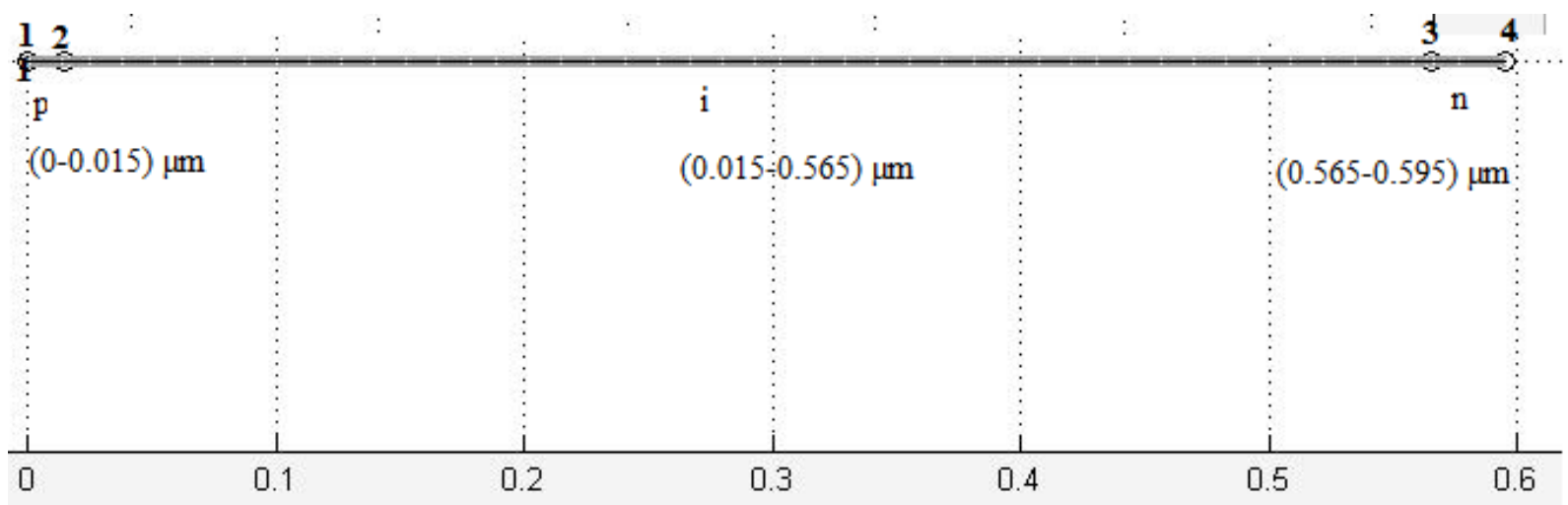

Figure 1. One dimensional structure of single junction $\mathrm{p}-\mathrm{i}-\mathrm{n}$ a-Si:H. Boundary 1 and 4 are interface between metal and device, where boundary 2 represents the interface between layer $p$ and $i$ and boundary 3 represents the interface between layer $i$ and $n$

We have used the modified Poisson and continuity (for electrons and holes) equations [8]. They were modelled to take account the potential electrostatic considering doping concentration, free charge carrier and its trapped component in amorphous structure. The boundary condition applied to the structure involve the contact and non contact device area to metal. We have applied Dirichlet boundary condition to define the magnitude of potential and charge carrier concentration which passed through the junction of $p$ and $n$ layers to the metal contact and also for intra-connection between $\mathrm{p}$-i-n layers. Its electrostatic potentials of the material were calculated as the sum of the external voltages and the logarithmic energy equation which corresponds to changes in dopant concentration [8]. For other boundaries, Neumann condition have applied [10]. 
Table 1. Input Parameters of simulation

\begin{tabular}{ll}
\hline \multicolumn{1}{c}{ Parameters } & Value \\
\hline Permitivity $(\epsilon)$ & $11.8 \mathrm{~F} / \mathrm{cm}$ \\
Temperature $(T)$ & $300 \mathrm{~K}$ \\
flux of photon $\left(G_{0}\right)$ & $10^{17} \mathrm{~cm}^{-2} \mathrm{~s}^{-1}$ \\
Transmission factor $(P)$ & 0.71 \\
Light absorbtion coefficient of a-Si $(\alpha)$ & $22222\left(\mathrm{~cm}^{-1}\right)$ \\
Intrinsic concentration $\left(n_{i}\right)$ & $6.019 \times 10^{10} \mathrm{~cm}^{-3}$ \\
Donor concentration $\left(N_{D}\right)$ & $8.8 \times 10^{11} \mathrm{~cm}^{-3}$ \\
Acceptor concentration $\left(N_{A}\right)$ & $1 \times 10^{17} \mathrm{~cm}^{-3}$ \\
Electron diffusion $\left(D_{n}\right)$ & $40 \mathrm{~cm}^{2} / \mathrm{s}$ \\
Electron diffusion $\left(D_{p}\right)$ & $4 \mathrm{~cm}^{2} / \mathrm{s}$ \\
Rasio between ionize and neutral charges $(c)$ & 50 \\
Thermal velocity by neutral bonding $\left(V_{t h} \sigma_{N}\right)$ & $10^{-11} \mathrm{~cm}^{-3} \mathrm{~s}^{-1}$ \\
Minimum density at donor and acceptor $\left(g_{m i n}\right)$ & $10^{16} \mathrm{~cm}^{-3} \mathrm{eV}^{-1}$ \\
Donor energy $\left(E_{D}\right)$ & $0.088 \mathrm{eV}$ \\
Acceptor energy $\left(E_{A}\right)$ & $0.053 \mathrm{eV}$ \\
minimum energy of conduction band $\left(E_{m c}\right)$ & $0.65 \mathrm{eV}$ \\
Energy of valence band $\left(E_{v}\right)$ & $0.15 \mathrm{eV}$ \\
Mesh & 0.00145 \\
\hline
\end{tabular}

\section{Result and Discussion}

The accumulation of charges in the junction area creates an electrostatic potential. The simulation results are electrostatic potential data on all parts of the device. The performance of the potential data for a p-i-n junction device is shown in Figure 1 and presented for a voltage of $0 \mathrm{~V}$ where the band gap energy of intrinsic part is $1.7 \mathrm{eV}$.

From both ends of the device terminal, the potential difference is almost $0 \mathrm{~V}$. The curve produces the high increment when the program was taken into account for $p$ and $i$ layers. The dopant addition in these layers causes the increase potential, based on the Poisson equation, while the intrinsic semiconductor have contributed to change of electrostatic potential at the middle part of the device. To observe the effect of difference of energy gap applied to the intrisic layers, we need to determine all potential data produced at the junction layers. 


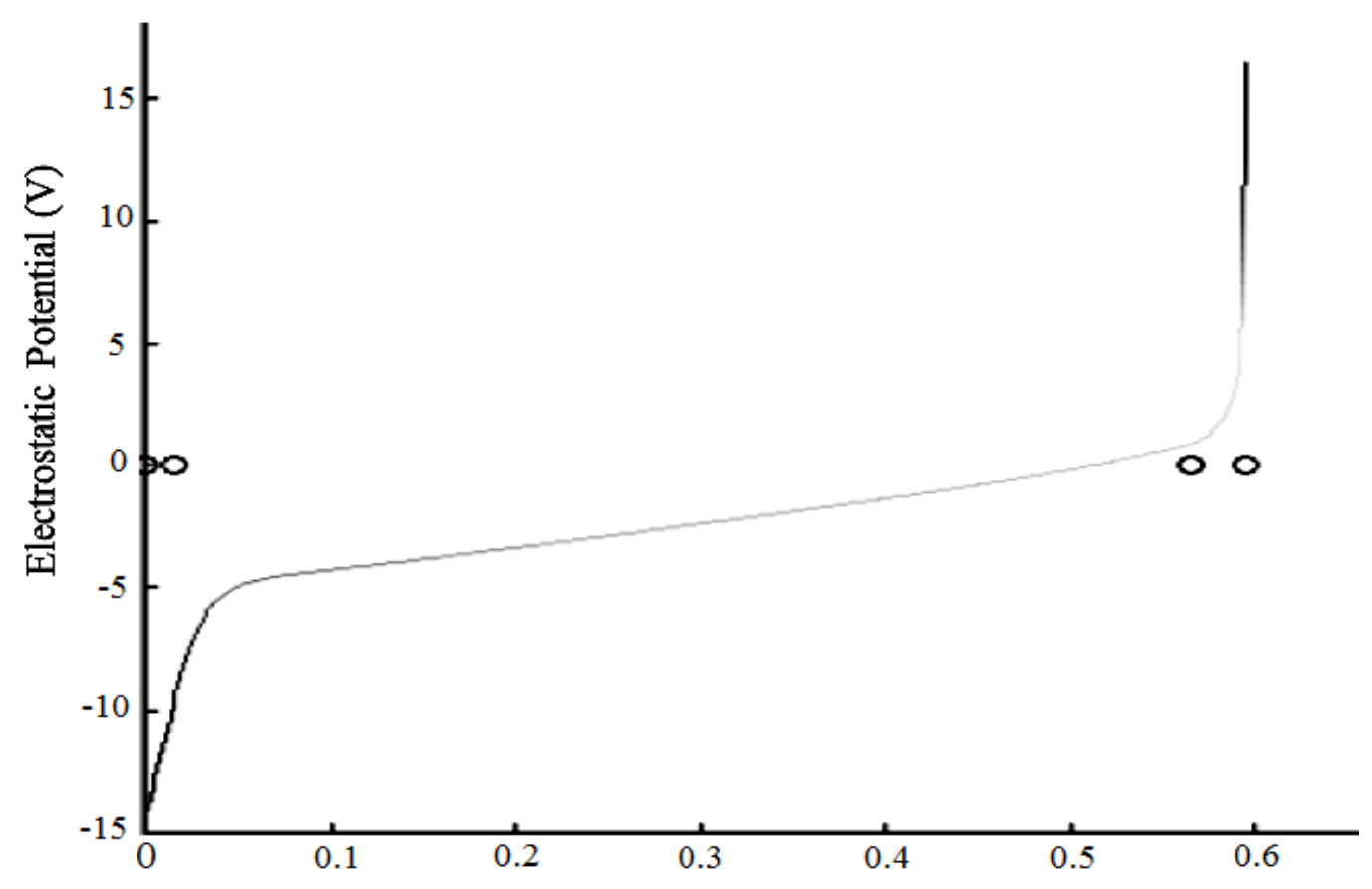

Thickness $(\mu \mathrm{m})$

Figure 1. Profile of electrostatic potential of a-Si:H p-i-n junction solar cell with the thickness of $0.015 \mu \mathrm{m} / 0.55 \mu \mathrm{m} / 0.03$ performed at band gap energy of intrinsic part of $1,7 \mathrm{eV}$ and terminal voltage of $0 \mathrm{~V}$

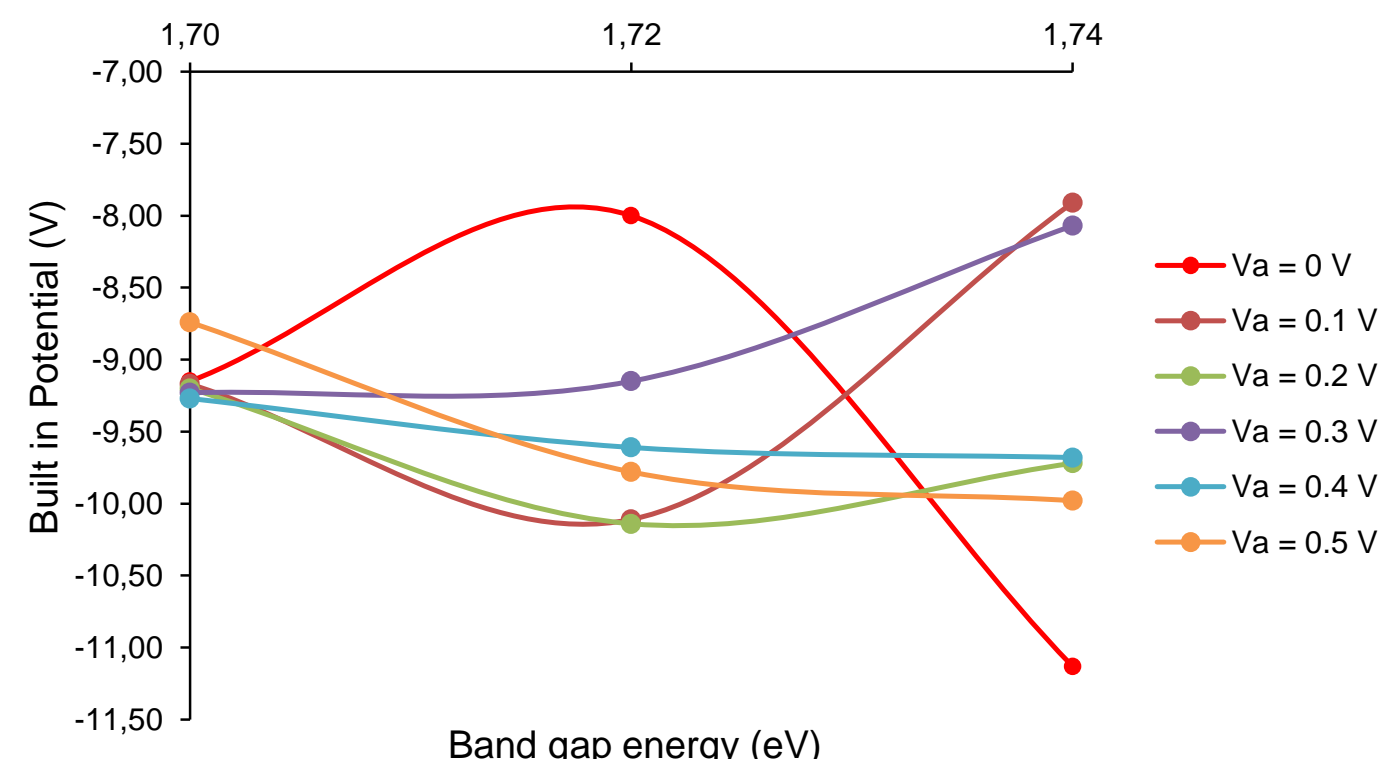

Figure 2. Built in potential at the $p$-i junction when the energy gap of the intrinsic layer is varied by $1.70 \mathrm{eV}, 1.72 \mathrm{ev}$ and $1.74 \mathrm{eV}$ 
The data of built in potential obtained by the simulation perform that all band gaps of intrinsic layer are negative numbers. These has a good agreement that negative charges were accumulated at the junction of $p$ and $i$ layers. At energy gap of $1,72 \mathrm{eV}$, the increasing built potential takes place only on terminal output of $0 \mathrm{~V}$. The highest built in potential were supported by the number of carrier charge. But this condition were not staying longer when the energy rising up to $1.74 \mathrm{eV}$.

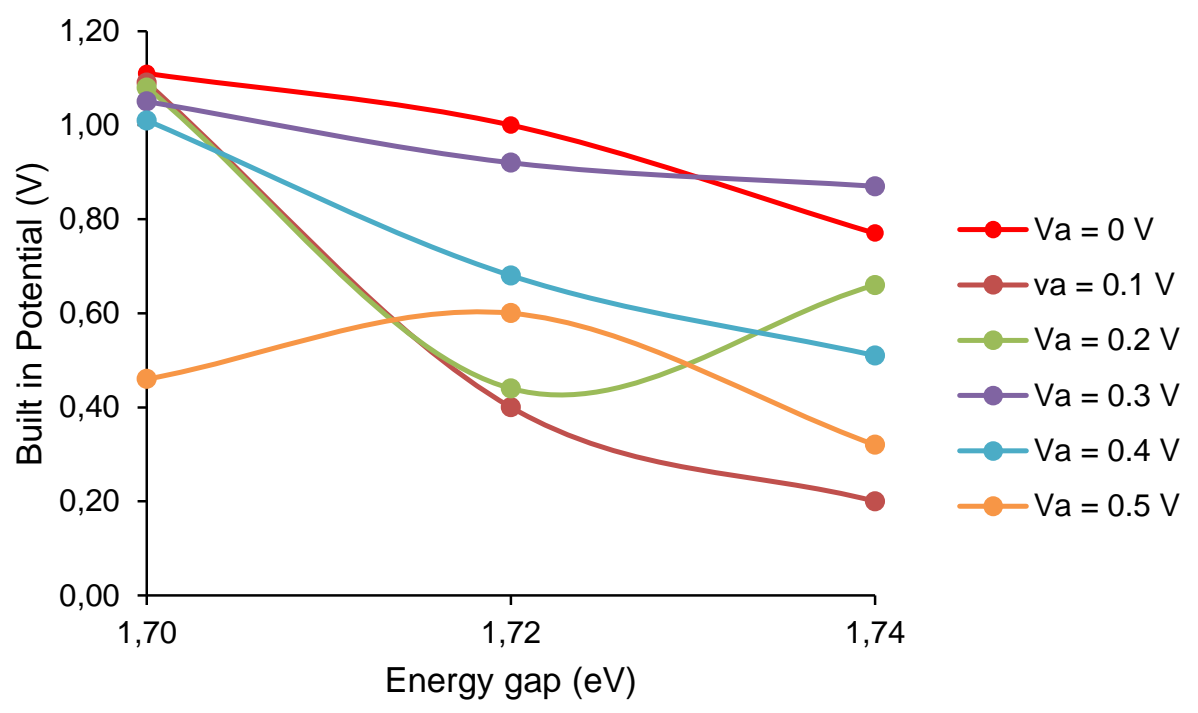

Figure 3. Built in potential at the i-n junction when the energy gap of the intrinsic layer is varied by $1.70 \mathrm{eV}, 1.72 \mathrm{ev}$ and $1.74 \mathrm{eV}$

All built in potential data is positive, which means that the hole dominates the charge carrier in the i-n junction area. Almost all potential data decreased when the energy gap of layer i was increased by $1.72 \mathrm{eV}$. When the energy gap of layer $\mathrm{i}$ is increased to $1.74 \mathrm{eV}$, the built in potential calculation for all output voltage data has decreased, except for the voltage of $0.2 \mathrm{~V}$.

\section{Conclusion}

The electrostatic potential distribution of amorphous silicon based solar cells, with a p-i-n linkage structure, has different profiles when analyzed at various output voltages. Negative potential performs electron charges accumulated at the junction of $p$ and $i$ layers, where its positive number represent the hole charges at i-n junction. The application of different energy gaps in the i-layer has a significant effect on the built-in potential of the two junctions ( $p-i$ and $i-$ $\mathrm{n}$ ). The device has a significant change in built in potential when the output voltage is $0 \mathrm{~V}$. When the energy gap of layer $\mathrm{i}$ is $1.72 \mathrm{eV}$, the device has the highest potential and then drops drastically at $1.74 \mathrm{eV}$. A decrease in built in potential due to an increase in the energy gap of the intrinsic layer occurs at all output voltages, except at $0.3 \mathrm{~V}$. 


\section{References}

[1] R Kaplan and B Kaplan, 2001, Built-in Potential Measurements in a-Si:H p-i-n Solar Cells, Turk J Phys, volume 25, pp 375 - 383.

[2] A Siregar, 2011, Pengaruh Konsentrasi Ekstrak Antosianin Pomegranate Fruits (Buah Delima) sebagai Dye-Sensitizer terhadap Efisiensi Sel Surya jenis DSSC (Dye Sensitized Solar Cell, . Jakarta, Universitas Pendidikan Indonesia

[3] E Purwandari and T Winata, 2012, Optimasi Tekanan Deposisi dalam Simulasi Efisiensi Sel Surya, Gradien, volume 8(1), page 716-721.

[4] M Hack and M Shur, 1985, Physics of Amorphous Silicon Alloy p-i-n Solar Cells. J. Appl. Phys., volume 58(2), page 997-1020.

[5] K Taretto, U Rau, and J H Werner, 2003, Closed-Form Expression for The Current/Voltage Characteristics of pin Solar Cells, Appl. Phys. A., volume 77, page 865-871.

[6] Zhu, Kalkan, Hou, and Fonash, 1999, Application of AMPS-1D for Solar Cell Simulation. The America Institute of Physics, volume 4(1), page 309-314.

[7] Kabir, Shahahmadi, Lim, Zaidi, Sopian, and Amin, 2009, Amorphous Silicon SingleJunction Thin-Film Solar cell Exceeding 10\% Efficiency by Design Optimization, International Journal Photoenergy, (460919)7.

[8] I Usman, 2006, Penumbuhan Lapisan Tipis Silikon Amorf Terhidrogenisasi dengan Teknik HWC-VHF-PECVD dan Aplikasinya pada Sel Surya, Disertasi, Bandung: ITB.

[9] Olthof, Kleeman, Lussem, and Leo, 2010, Built-in Potential of a Pentacene p-i-n Homojunction Studied by Ultraviolet Photoemission Spectroscopy, Matter. Res. Soc. Symp. Proc., 1270-(2), 09-49.

[10] E Purwandari and T Winata, 2013, Efficiency Calculation Analysis of A-Si:H Solar Cells for Determination of Optimum Filament Temperature in Material Deposition, Jurnal IImu Dasar, volume 14(1), page 29-32. 